\title{
Has the Brexit Vote Affected the United Kingdom's Largest Trading Partners?
}

\author{
By L. Jan Reid
}

On June 23, 2016, United Kingdom (UK) voters decided to leave the European Union (EU), thereby starting a process commonly known as Brexit. British Prime Minister Theresa May invoked EU Article 50 on March 29, 2017. The invocation of EU Article 50 puts the UK on a course to leave the EU by the end of March 2019. Meanwhile, the UK remains a full member of the European Union. The major economic impact of Brexit to date is the decline in the value of the British Pound (GBP), which fell from USD \$1.467 on June 20, 2016 to \$1.204 on January 16, 2017. A decline in the value of a country's currency means that its products will be less expensive on the world market. Ceteris paribus, a decline also decreases a country's unemployment rate, and its citizens will pay more for imported goods. Data was collected on the UK and its ten largest trading partners to determine whether those eleven countries have been harmed by the Brexit vote. Those countries are: Belgium, China, France, Germany, Ireland, Italy, the Nether-lands, Spain, the United Kingdom, and the United States. For each country, the paper estimates the effect of Brexit on exchange rates, GDP, unemployment, and other macroeconomic and political variables.

Keywords: Brexit, Consumption, Exchange Rates, Gross Domestic Product, Unemployment.

\section{Introduction}

On June 23, 2016, United Kingdom (UK) voters decided to leave the European Union (EU), thereby starting a process commonly known as Brexit. Since the Brexit vote, there have been several predictions of economic and political disaster related to a post-Brexit world. The London School of Economics' Center for Economic Performance forecasted a loss in UK Gross Domestic Product of from 2.2\%-9.5\% and a significant decrease in UK trade. ${ }^{1}$ The Economist Group estimates that for every point decline in UK GDP, the other European countries will experience a GDP decline of from $0.33 \%$ to $0.50 \%$, which will result in lower profits for European companies.

Figure 1 gives real GDP growth for the UK and the Euro Area for the period 2016 Q2 to 2017 Q3.

\footnotetext{
${ }^{*}$ President, Coast Economic Consulting, USA.

${ }^{1}$ Trade is defined as imports plus exports.
} 
Figure 1. UK and EU Real GDP Growth from 2016 Q2 to 2017 Q3

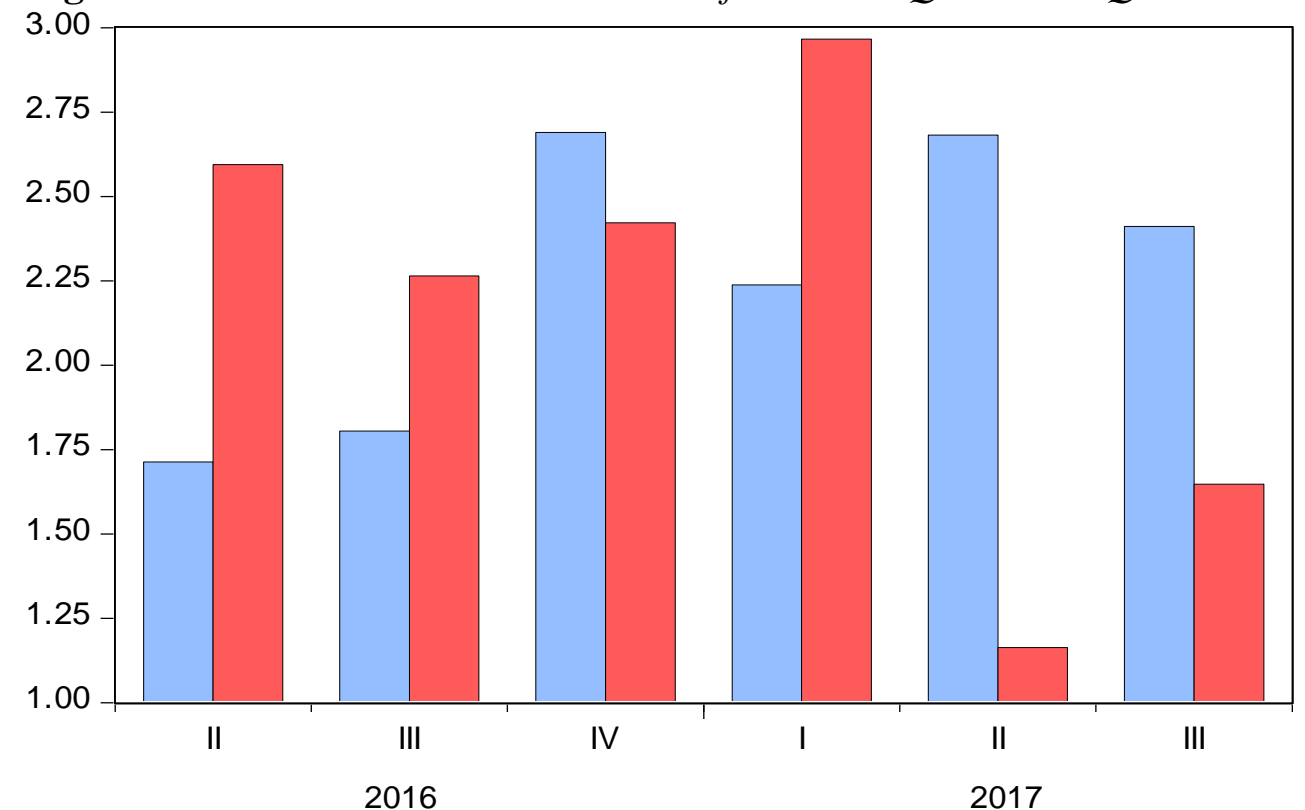

$\square$ EUGDP_GROWTH $\square$ UKGDP_GROWTH

As shown in Figure 1, GDP growth for the period 2016 Q2 to 2017 Q3 ranged from $1.71 \%$ to $2.69 \%$ for the EU and from $1.16 \%$ to $2.97 \%$ for the UK.

This paper examines the economic effect of the Brexit vote on the United Kingdom, and on its ten largest goods trading partners as defined by HM Revenue and Customs (2016). Macroeconomic data was collected for eleven countries, seven of which are current members of the European Union. These eleven countries are Belgium, China, France, Germany, Ireland, Italy, the Netherlands, Spain, Switzerland, the United Kingdom, and the United States of America (US). Table 1 provides the value of imports, exports, and trade for each of these ten countries.

Future trade negotiations may have a positive or negative impact on imports, exports, and GDP for the UK and the ten countries listed in Table 1 below.

Table 1. 2015 Top Ten Trading Partners of the United Kingdom in Millions of GBP

\begin{tabular}{|l|c|c|c|}
\hline Country & Imports & Exports & Trade \\
\hline Germany & 60,860 & 30,382 & 91,242 \\
\hline United States & 35,291 & 45,278 & 80,568 \\
\hline China & 36,103 & 18,071 & 54,174 \\
\hline Netherlands & 30,995 & 17,311 & 48,306 \\
\hline France & 24,050 & 17,862 & 41,912 \\
\hline Belgium & 20,509 & 11,602 & 32,111 \\
\hline Switzerland & 8,895 & 22,244 & 31,140 \\
\hline Ireland & 12,527 & 16,718 & 29,245 \\
\hline Italy & 15,818 & 8,419 & 24,237 \\
\hline Spain & 14,000 & 8,861 & 22,861 \\
\hline
\end{tabular}


For each country, the paper provides short-term results by comparing economic results for the second quarter of 2016 to economic results for the period 2016 Q3 to 2017 Q3. Long-term economic results for the same eleven countries are then estimated for the period 2018-2030. The 2018-2030 time period was chosen because it is the period used by Kierzenkowski et. al. (2016) who provided one of the more extreme forecasts and were the only authors who adequately defined the meaning of the phrase "long-term" (see section "Economic Forecasts").

The paper also estimates the political effect of Brexit on elections in eleven European countries from 2016 to 2019. These countries are Austria, Denmark, Finland, France, Germany, Italy, the Netherlands, Hungary, Poland, Portugal, and Sweden.

These countries were chosen because they had elections scheduled after June 23, 2016; each country had an identifiable nationalist or eurosceptic party; and public opinion polling data was available for each country.

\section{Hypotheses}

For the UK, the paper hypothesized that Brexit will result in an increase in GDP and a decrease in unemployment rate. For the UK's ten largest trading partners, the paper hypothesized that Brexit will result in slight declines in GDP and an increase in civilian unemployment rates. Empirical tests of these hypotheses are provided in sections "Short-Term Economic Effects" and "Long Term Economic Effects".

\section{Literature Review}

The literature review explored the nine subjects discussed below. These subject areas were chosen because (taken together) they help explain much of the economic and political effect of Brexit. As discussed in section "Analysis of Results", the economic forecasts have affected the political results. Consumer confidence affects consumption, which affects GDP; and foreign direct investment is a subset of total investment, which also affects GDP. The actions of central banks will have a material effect on economic results because the central banks effectively control interest rates through their monetary stimulus programs.

1. Economic Forecasts

2. Political and Economic Risk

3. Economic Data

4. Consumer Confidence

5. Foreign Direct Investment

6. Financial Effects

7. The Effect of Brexit on the UK's Top Trading Partners

8. The Central Banks' Response to Brexit

9. Political Effects of Brexit 
Each of these subjects is discussed below.

\section{Economic Forecasts}

The Organization for Economic Co-Operation and Development (OECD) predicted that GDP would be 3\% smaller in 2020 and 5\% smaller in 2030, equivalent to a cost per household of 2,200 British pounds (GBP) by 2020 and 3,200 GBP by 2030. (Kierzenkowski et al. 2016)

In a note to investors, TD Economics warned that "We estimate that confidence and financial spillovers from a 'leave' result could shave 0.5 to 1.0 percentage points off GDP growth for the U.S. and Canada in the second half of 2016" (Van Santvoort 2016).

The Institute for Fiscal Studies found that "Britain could be up to $£ 70$ billion worse off if it leaves the Single Market after Brexit because of slower growth" (Swinford 2016).

Sampson T. (2017) reviewed the research literature and found that "Overall, the research literature displays a broad consensus that in the long run Brexit will make the United Kingdom poorer because it will create new barriers to trade, foreign direct investment, and immigration." (174)

In their fall 2016 forecast, the European Commission (EC) predicted a slight decline in Euro Area real GDP growth when compared to their preBrexit Spring 2016 forecast. The European Commission forecast a real GDP growth rate of $1.6 \%$ for 2017 compared to $1.9 \%$ in their spring 2016 forecast. However, in winter 2016, the EC forecast a real GDP growth rate of $1.9 \%$ in 2017, which was identical to their spring 2016 forecast (European Commission 2016).

The European Commission has explained that "risks to the forecast have risen in recent months and are clearly tilted to the downside, including because of the UK 'leave' vote, which has raised uncertainty and can be seen as an indicator of heightened policy risks in the current volatile political environment" (European Commission 2016).

Obstfeld M. (2016) has pointed out that:

equity markets fell and corporate bond interest rates rose on June 24, 2016, as markets began to price in the unexpected result of the U.K. referendum. Equity markets recovered quite quickly. Corporate bond yields dropped after the initial upward spike, and government bond yields - especially those of gilts - dropped dramatically worldwide in real terms.

Oxford Economics has pointed out that "The initial global market reaction to the UK Brexit vote was very negative and in our view overdone" (Slater 2017) Their most recent forecasts see UK growth dropping to $1.4 \%$ a year in 2017-18, down from 2.2-2.3\% a year before. Oxford Economics predicts that growth will decline by $0.2 \%$ a year in the Eurozone and from $0.5 \%$ in 2016 to $0.3 \%$ in Japan in 2017. 
For the period 2016 Q3 to 2017 Q3, the actual growth rate of real GDP was $1.5 \%$ in the UK and $2.5 \%$ in the EU. Real GDP growth was $1.6 \%$ in Japan from 2016 Q2 to 2017 Q2 (Federal Reserve Economic Data 2017).

The vast majority of the forecasts cited above have been shown to be inaccurate. Andy Haldane, the Bank of England's chief economist, said that:

forecasters got it wrong when they predicted a sharp economic downturn if Britain voted to leave the European Union . . the country's strong economic performance since the June referendum has been a surprise, and the economic forecasting profession "is to some degree in crisis" (Associated Press 2017).

BBC News has reported that the UK economy grew by $0.6 \%$ between July 2016 and September 2016 and that the fall in the value of the GBP has not led to a significant increase in UK exports (BBC News 2017).

\section{Political and Economic Risk}

A number of authors have addressed the topic of Brexit-related risk. Although this paper examines actual economic changes rather than the risk of economic changes, risk-related papers are included for comparison purposes.

Begg I. (2017) argues that the UK aspiration of retaining market access while limiting immigration is unlikely to be attainable.

Scuira (2017) addresses the potential disintegration of the European community and the negative effect of Brexit on long-held integrationist principles. Welfens (2017) argues that there is a risk that the UK will have less access to the European market, the pound will devalue by $20 \%$, and UK inflation will increase.

Van Reenen J. (2016) argues that "Compared with remaining in the European Union, there will inevitably be higher trade costs with the rest of Europe, which accounts for about half of all U.K. trade. This will mean lower trade and foreign investment, and thus lower average U.K. incomes."

Belke A. and Gros D. (2017) reviewed the literature and found that Brexit will lead to a significant disruption of trade links and will impose economic costs on both sides. However, the EU27 would bear only a disproportionally small share of the total cost.

\section{Economic Data}

There is considerable debate concerning the accuracy of the Chinese government's economic data, particularly GDP data. Frik Els (2017) has reported that:

Independent research house Capital Economics' measure of the Chinese economy - the China Activity Proxy or CAP - uses a combination of weighted data including electricity usage, seaport cargoes, floor space 
under construction and passenger and freight traffic to gauge activity across a wide section of the economy.

According to Capital Economics research, China's year-on-year GDP growth rate dropped below 4\% in December last year (as metals, iron ore and coal prices hit multi-year lows) and stayed below 5\% during the first half of 2016.

But since then growth has picked up markedly hitting 6.8\% in November. That's the fastest pace since 2013 using the Capital Economics gauge and the first time since 2011 that the two measures have converged (Els 2017).

\section{Consumer Confidence}

Eric Lascelles, chief economist at RBC Global Asset Management, has argued that "Extremely uncertain public policy should be a drag that constricts growth." (Hannon 2017)

Paul Hannon has pointed out that:

The U.K.'s June decision to leave the European Union has been the biggest test of how uncertainty affects confidence and investment.

After a dip in the immediate aftermath of the vote, optimism has returned even as uncertainty about the shape of Britain's future relationship with the EU remains high. That resilience has surprised the Bank of England, which admits its growth forecasts for 2016 were more gloomy than has proved warranted (Hannon 2017).

Many economists believe that this increase in confidence will lead to an increase in consumption, thereby raising real GDP. UK GDP growth was $0.15 \%$ in 2016 Q1, 0.60\% in 2016 Q2, 0.50\% in 2016 Q3, and 0.66\% in 2016 Q4.

The Bank of England ${ }^{2}$ has found that British households change their consumption by significantly more in reaction to temporary and unanticipated falls in income than to rises of the same size. (Bunn et al. 2017)

Thus, most economists would have predicted a decline in consumption because the economists believed that incomes would have fallen because of the Brexit vote. However, this view was apparently not shared by UK households, at least in the short term. In contrast, it appears that UK households believed that Brexit would increase, not decrease, household income.

Figure 2 compares UK consumption for the period 2015 Q2 to 2017 Q2.

\footnotetext{
${ }^{2}$ The Bank of England is the United Kingdom's central bank and is functionally similar to the U.S. Federal Reserve Board.
} 
Figure 2. UK Consumption from 2015 Q2 to 2017 Q2 in Billions of UK Pounds

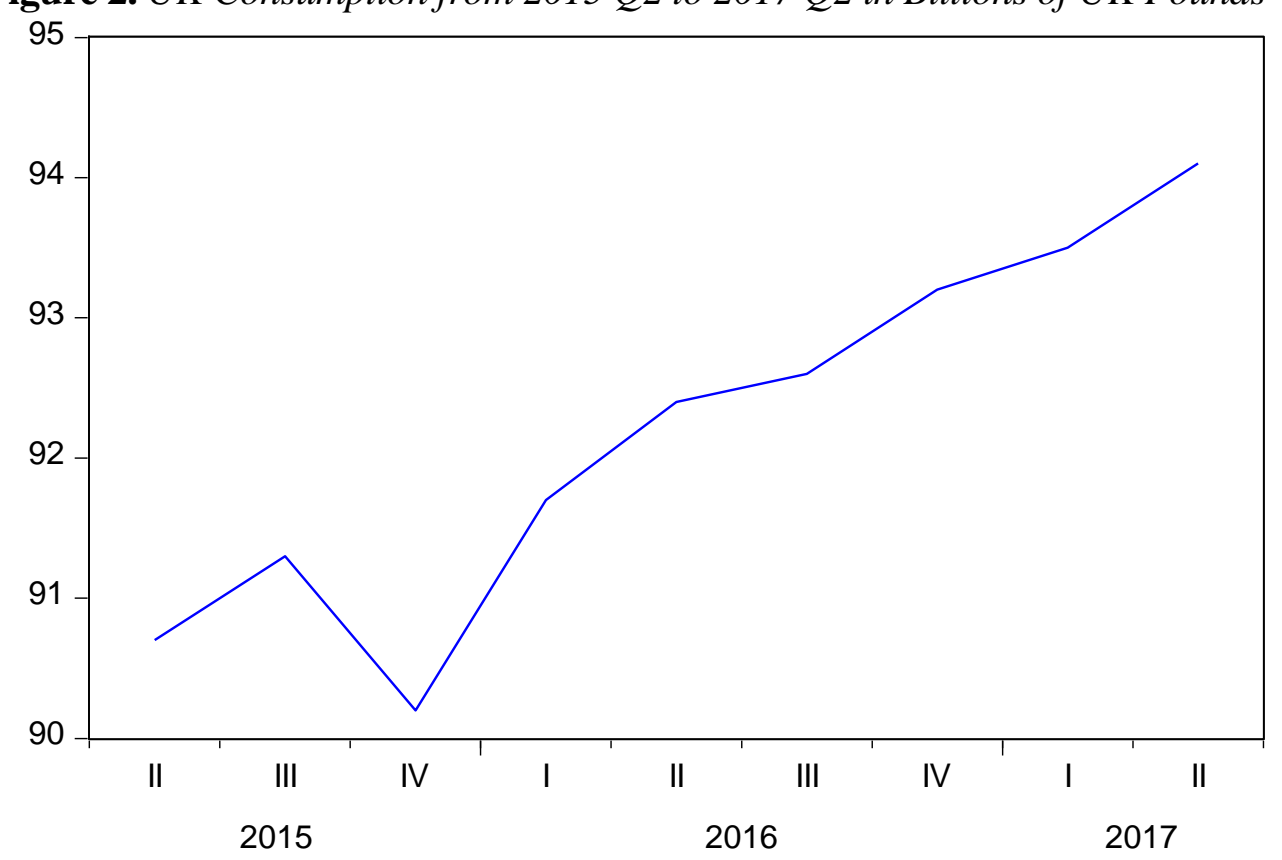

Foreign Direct Investment (FDI)

Claudia De Meulemeester reported that:

European experts from the World Pensions Council (WPC) and the University of Bath have argued that, beyond short-lived market volatility, the long term economic prospects of Britain remain high, notably in terms of country attractiveness and foreign direct investment (FDI) . . . The UK is certainly a major recipient of FDI. In 2014, it held the second largest stock of inward investment in the world, amounting to just over $£ 1$ trillion or almost $7 \%$ of the global total. ... On a per capita basis, the UK is the clear front-runner among major economies with a stock of FDI around three times larger than the level in other major European economies and 50\% larger than in the US (De Meulemeester 2016).

Capital Economics has found that:

Concerns about a drying up of foreign direct investment if Britain votes to leave the European Union are somewhat overblown. Access to the single market is not the only reason that firms invest in Britain. Other advantages to investing here should ensure that foreign firms continue to want a foothold in the country. It is likely Britain would remain a haven for foreign direct investment flows even if it was outside of the European Union. Of course, we could see a period of weak foreign direct investment inflows as the United Kingdom's new relationship is renegotiated. However, if Britain can obtain favourable terms, then foreign direct investment would probably recoup this lost ground (Capital Economics 2016). 


\section{Financial Effects}

Wyman (2016) estimated that Brexit will cause a loss of up to 35,000 jobs in the UK financial sector and a loss of 3-5 billion GBP of tax revenue per annum. Miethe and Pothier (2015) argue that "The UK's reliance on financial service exports to the EU will also weaken the UK's bargaining position in any future negotiations with the EU" (Miethe and Pothier 2016: 371).

Ringe (2016) presents the much more optimistic view that the effect of Brexit on financial services will be miniscule, if not irrelevant. He shows that the economic and political incentives of "both the UK and of the EU27 are strongly in favour of maintaining Single Market access for financial services" (Ringe 2016: 11).

\section{The Effect of Brexit on the United Kingdom's Top Trading Partners}

British Prime Minister Theresa May invoked EU Article 50 on March 29, 2017 (The Economist 2017). As a result, the EU lost its second-largest economy, its third-largest populated country, and the financial center of Europe.

In 2015, the EU had a budget of over 141 billion euros. The UK, the EU's second-largest contributor, contributed $\$ 17.8$ billion euros, or approximately $12.57 \%$ of the EU's total budget (HM Treasury 2015: 7, 13-14). Thus, the departure of the UK from the EU will result in an additional financial burden for the remaining contributors unless the budget is reduced accordingly.

Seeking Alpha has found that "While China may enjoy trade gains with the UK, trade with Europe as a whole may suffer. Europe is China's largest trade partner, and the shock from Brexit will almost certainly cause a continental slowdown. The immediate fallout from Brexit was a swift depreciation of the Euro. This depreciation created a relative price increase for foreign goods, which may decrease demand for Chinese products if $\mathrm{PBoC}$ or ECB do not react quickly with monetary policy actions" (Seeking Alpha 2016).

Chinese economic analysts have mixed views concerning the effect of Brexit on China. Wang Yiwei believes that London could lose its role as the Euro's main financial trading center, which would affect China's Euro financing channels. Zhu Haibin warns that Brexit might disrupt China's capital flows, exchange rate, and monetary policies. Zhao Hongwei believes that the UK will be the leading voice in granting China market economy status (MES) because the UK will be able to make an independent decision on granting MES once it has left the EU. Finally, Feng Zhongping believes that Brexit presents advantages for China because a more independent UK will be freer to negotiate financial and trade deals with China (Stanzel 2016).

\section{The Central Banks' Response to Brexit}

The Bank of England (BOE) responded to the Brexit vote by lowering the Bank Rate from $0.50 \%$ to $0.25 \%$ on August 4,2016 and by engaging in other types of monetary stimulus (Bank of England 2016). 
Because of these actions, recession was avoided "but only just and only because the Bank's nine-strong monetary policy committee (MPC) assumes that lower interest rates, a new scheme to encourage commercial banks to pass on lower borrowing costs and additional money creation will boost activity over the coming months and years" (The Guardian 2016).

The BOE was also expected to provide $£ 100$ billion in funding for commercial banks, reduce interest rates to $0.1 \%$, and possibly purchase more gilts and corporate bonds in 2017 (The Guardian 2016).

Brexit supporters have been critical of the BOE's actions, and believe that the BOE's stimulus program was premature. Nevertheless, it appears that the BOE program has been effective. BOE governor Mark Carney has argued that "if the Bank's Monetary Policy Committee had not acted in this timely, coherent and comprehensive way an output gap of 1.5 per cent of GDP would have opened up in the UK economy, implying around a quarter of a million lost jobs" (Chu 2016).

It would be reasonable to assume that other central banks would have taken concrete actions to forestall what they believe will be the negative effects of Brexit. However, neither the European Central Bank (ECB) nor the People's Bank of China (PBOC) have taken such actions. PBOC governor Zhou Xiaochuan has stated that "The People's Bank of China is closely monitoring events surrounding Britain's vote to leave the European Union, but more study is needed to understand its full implication" (Lawder 2016).

European Central Bank President Mario Draghi asked eurozone governments to help the ECB by enacting growth-boosting overhauls, because central banks are moving closer to the limits of what their stimulus policies can achieve (Fairless and Buell 2016).

\section{Political Effects}

EU Council decisions made by qualified majority voting can be blocked if at least four members of the Council form a blocking minority. This led to a coalition among the UK, Germany, and other northern European countries in matters of budget discipline and on the use of German banks to guarantee German deposits in southern European banks. After Brexit, Germany lost their blocking minority (Eur-Lex 2008).

Matthijs (2017) has argued that "Antiestablishment parties on both the right and the left have gained ground at the expense of Christian Democratic and Social Democratic parties". The effect of Brexit on election results are discussed in section "Political Effects" below.

Outside of the UK, many eurosceptic leaders expected other countries to follow the UK's example and leave the EU. However, public opinion polls taken one month after the Brexit vote found a decline in support both for eurosceptic political parties and for countries leaving the EU (Oltermann et al. 2016). These polls are summarized in Table 2, below. 
Table 2. July 2016 Public Opinion Polls in EU Countries

\begin{tabular}{|c|c|c|c|}
\hline Country & Entity Polled & $\begin{array}{c}\text { Voter Support (July } \\
\text { 2016) }\end{array}$ & $\begin{array}{c}\text { Previous Voter } \\
\text { Support }\end{array}$ \\
\hline Germany & $\begin{array}{c}\text { Alternative für } \\
\text { Deutschland }\end{array}$ & $11 \%$ & $14 \%$ \\
\hline Netherlands & Freedom Party & 30 seats & 33 seats \\
\hline Austria & Remain in EU & $52 \%-30 \%$ & $51 \%-49 \%$ \\
\hline Denmark & Remain in EU & $69 \%$ & $59.8 \%$ \\
\hline Finland & Remain in EU & $59 \%$ & $56 \%$ \\
\hline Italy & Northern League & $12.4 \%$ & $13.1 \%$ \\
\hline
\end{tabular}

\section{Methodology}

The economic portion of the empirical study is composed of two general parts: short-term economic effects and long-term economic effects. Macroeconomic data was collected for the period 1995 Q1 to 2017 Q3, and monthly data for the period January 1995 to December 2017. The paper estimates the effect of Brexit on private consumption, domestic inflation, exchange rates, foreign direct investment (FDI), GDP, trade, and unemployment, using the model described in section "Short Term Economic Models".

Macroeconomic data was collected from the following sources: Eurostat (n.d.a, n.d.b, 2017a, 2017b), The Federal Reserve Bank of St. Louis, the National Bureau of Statistics of China (2017), the Organization for Economic Co-Operation and Development (OECD), and Trading Economics. ${ }^{3}$

Only annual data, but not quarterly data, was available for all countries for all years. It was necessary to have quarterly or monthly data for the regression analysis. Otherwise, there would have been an insufficient number of observations and the regression results would be biased. Therefore, quarterly data was created from annual data using the following method:

- A ratio of existing quarterly data as a percentage of annual data was created. The ratio was then multiplied by existing annual data for each year.

- For example, the approximate quarterly ratios (rounded to four digits) for German export data were Q1 0.2436, Q2 0.2479, Q3 0.2527, and Q4 0.2558 , and 2015 exports were $1,334.8330$ billion euros.

- For 2015:Q1, this method yielded exports of 345.547 billion euros $(0.2436 * 1,334.833=345.547)$.

\section{Short Term Economic Models}

For each country, seven different first order Auto Regressive Moving Average (ARMA) regression models were used to estimate the macroeconomic variables listed in the first paragraph of section "Methodology". A White covariance matrix was used to account for the effect of heteroskedasticity in the

\footnotetext{
${ }^{3}$ Trading Economics data is available by subscription.
} 
data. Because changes to macroeconomic variables are affected by factors other than the Brexit vote, an Autoregressive AR(1) term and a moving average term MA(1) were used as proxies for all non-Brexit factors, and a dummy variable (B) was used to account for the effect of Brexit. ${ }^{4}$

The regression equations are: ${ }^{5}$

$$
\begin{aligned}
& \mathrm{C}=\alpha+\beta_{1} \mathrm{~B}+\beta_{2} \mathrm{~A}+\beta_{3} \mathrm{M} \\
& \mathrm{E}=\alpha+\beta_{1} \mathrm{~B}+\beta_{2} \mathrm{~A}+\beta_{3} \mathrm{M} \\
& \mathrm{F}=\alpha+\beta_{1} \mathrm{~B}+\beta_{2} \mathrm{~A}+\beta_{3} \mathrm{M} \\
& \mathrm{G}=\alpha+\beta_{1} \mathrm{~B}+\beta_{2} \mathrm{~A}+\beta_{3} \mathrm{M} \\
& \mathrm{I}=\alpha+\beta_{1} \mathrm{~B}+\beta_{2} \mathrm{~A}+\beta_{3} \mathrm{M} \\
& \mathrm{T}=\alpha+\beta_{1} \mathrm{~B}+\beta_{2} \mathrm{~A}+\beta_{3} \mathrm{M} \\
& \mathrm{U}=\alpha+\beta_{1} \mathrm{~B}+\beta_{2} \mathrm{~A}+\beta_{3} \mathrm{M}
\end{aligned}
$$

where:
$A$ is an $\operatorname{AR}(1)$ term.
$\mathrm{B}$ is a dummy variable set equal to 0 in the quarterly models through $2016 \mathrm{Q} 2$, and set equal to 1 thereafter. In the monthly models, B is a dummy variable set equal to 0 through June 2016, and set equal to 1 thereafter.
$\mathrm{C}$ is private consumption.
$\mathrm{E}$ is the value of each country's currency in U.S. dollars.
$F$ is foreign direct investment.
$\mathrm{G}$ is real GDP.
I is the consumer price index for all items.
$\mathrm{M}$ is a MA(1) term.
$\mathrm{T}$ is trade, which the paper defines as imports plus exports.
$\mathrm{U}$ is the civilian unemployment rate.
$\alpha$ is the constant term.
$\beta_{1}, \beta_{2}$, and $\beta_{3}$, are the estimated coefficients.

\section{Long-Term Economic Models}

For each country, a Vector Auto Regression (VAR) model was used to estimate GDP. The regression equation is:

$$
\begin{aligned}
\mathrm{C}= & \alpha+\beta_{1} \mathrm{~B}+\beta_{2} \mathrm{C}(-1)+\beta_{3} \mathrm{C}(-2)+\beta_{4} \mathrm{~F}(-1)+\beta_{5} \mathrm{~F}(-2)+\beta_{6} \mathrm{G}(-1)+ \\
& \beta_{7} \mathrm{G}(-2)+\beta_{8} \mathrm{~N}(-1)+\beta_{9} \mathrm{~N}(-2)
\end{aligned}
$$

where:

$\alpha, \mathrm{B}, \mathrm{C}, \mathrm{F}, \mathrm{G}$ are defined above.

\footnotetext{
${ }^{4}$ In some cases, either the $\mathrm{AR}(1)$ or the MA(1) term was omitted in order to account for the effect of serially correlated residuals on the regression results.

${ }^{5} \mathrm{~A}$ first difference model was used in situations where the AR(1) process was non-stationary or to adjust for serially correlated residuals.
} 
$\mathrm{N}$ is net exports.

The (-1) and (-2) notations refer to one- and two period lags, respectively.

$\beta_{1}-\beta_{9}$ are the estimated coefficients.

\section{Political Models}

The paper estimated the effect of Brexit on voter support for a single far-right or nationalist party in public opinion polls in each of eleven European countries. The political parties in the study, and their candidates, are given in Table 3 below.

Table 3. European Nationalist Party Candidates

\begin{tabular}{|c|c|c|c|}
\hline Country & Candidate & Party & Presidential Election \\
\hline Austria & Norbert Hofer & Freedom & December 4,2016 primary \\
\hline Denmark & Kristian Dahl & $\begin{array}{c}\text { Danish People's } \\
\text { Party }\end{array}$ & June 17, 2019 general \\
\hline Finland & Undetermined & Finns & January 28,2018 primary \\
\hline France & Marine Le Pen & National Front & April 23, 2017 primary \\
\hline Germany & Albrecht Glaser & $\begin{array}{l}\text { Alternative für } \\
\text { Deutschland }\end{array}$ & $\begin{array}{c}\text { October } 22,2017 \\
\text { parliamentary }\end{array}$ \\
\hline Hungary & János Vollner & Jobbik & Spring 2018 parliamentary \\
\hline Italy & Beppe Grillo & $\begin{array}{c}\text { Five Star } \\
\text { Movement }\end{array}$ & $\begin{array}{l}\text { May 23, } 2018 \\
\text { parliamentary }\end{array}$ \\
\hline Netherlands & Geert Wilders & $\begin{array}{l}\text { Freedom and } \\
\text { Democracy }\end{array}$ & $\begin{array}{c}\text { March 15, } 2017 \\
\text { parliamentary }\end{array}$ \\
\hline Poland & $\begin{array}{c}\text { Mateusz } \\
\text { Morawiecki }\end{array}$ & Law and Justice & $\begin{array}{l}\text { November } 2019 \\
\text { parliamentary }\end{array}$ \\
\hline Portugal & Assunção Cristas & People's Party & $\begin{array}{l}\text { October } 2019 \\
\text { parliamentary }\end{array}$ \\
\hline Sweden & Jimmie Åkesson & $\begin{array}{c}\text { Sweden } \\
\text { Democrats }\end{array}$ & $\begin{array}{l}\text { September 9, } 2018 \\
\text { parliamentary }\end{array}$ \\
\hline
\end{tabular}

For each country, the paper used a first-order Auto Regressive Moving Average (ARMA) regression model combined with a White covariance matrix to account for the effect of heteroskedasticity in the data. Since changes to voter support (from poll to poll) are also affected by non-Brexit

issues, an Autoregressive AR(1) term and a moving average term MA(1) were used as proxies for all non-Brexit factors and a dummy variable (B) was used to account for the effect of Brexit. ${ }^{6}$

The regression equations are: ${ }^{7}$

$$
\mathrm{V}=\alpha+\beta_{1} \mathrm{~B}+\beta_{2} \mathrm{~A}+\beta_{3} \mathrm{M}
$$

\footnotetext{
${ }^{6}$ In some cases, either the $\operatorname{AR}(1)$ or the MA(1) term was omitted in order to account for the effect of serially correlated residuals on the regression results.

${ }^{7} \mathrm{~A}$ first difference model was used in situations where the AR (1) process was non-stationary or to adjust for serially correlated residuals.
} 
where:

$\mathrm{A}, \mathrm{B}$, and $\mathrm{M}$ are defined above.

$\mathrm{V}$ is a party's percentage of the vote in a public opinion poll.

$\beta_{1}, \beta_{2}$, and $\beta_{3}$, are the estimated coefficients.

\section{Short-Term Economic Effects}

As mentioned previously, Brexit will have both short-term (2016-2017) and long-term economic effects (2018-2030). Short-term estimates are given in Tables 4-5, and long-term estimates are given in Table 8 below.

Probabilities (ranging from 0 to 1 ) were calculated for each estimated coefficient. A probability of 0.05 indicates $95 \%$ confidence that the true coefficient is not zero. A probability of 0 indicates $99 \%$ confidence that the true coefficient is not 0 . Consistent with standard econometric practice, the true coefficient is assumed to be $0(0.00 \%$ change $)$ if the estimated probability is greater than 0.05 .

As shown in Tables 4 and 5, the model results indicate that Brexit caused:

- Consumption to rise in three countries, and have no effect in one country. ${ }^{8}$

- The exchange rate to fall in the United Kingdom, and have no effect in seven countries. Because exchange rates are a comparison of the value of a country's currency to the value of the U.S. dollar, it was not possible to calculate the effect of Brexit on the U.S. dollar.

- Foreign direct investment to rise in two countries, fall in one country, and be inconclusive in one country.

- Real GDP to rise in two countries, fall in one country, and have no effect in eight countries.

- Inflation to fall in four countries; rise in one country; and have no effect in six countries.

- No effect on trade in any of the eleven countries.

- The unemployment rate to fall in three countries, and have no effect in eight countries.

\footnotetext{
${ }^{8}$ The paper considers individual country model results to be inconclusive if there was no data; a shortage of observations; or serially correlated residuals.
} 
Table 4. Brexit Short Term (2016-2017) Effect on Consumption (Cons.), Exchange Rates, Foreign Direct Investment (FDI), and GDP

\begin{tabular}{|l|c|c|c|c|}
\hline Country & $\begin{array}{c}\text { Change in } \\
\text { Cons. }\end{array}$ & $\begin{array}{c}\text { Change in } \\
\text { Currency } \\
\text { Value }\end{array}$ & $\begin{array}{c}\text { Per Cent } \\
\text { Change in } \\
\text { FDI }\end{array}$ & $\begin{array}{c}\text { Change in } \\
\text { GDP }\end{array}$ \\
\hline Belgium & $0.00 \%$ & $0.00 \%$ & $-154.63 \%$ & $-0.35 \%$ \\
\hline China & NA & $0.00 \%$ & $25.60 \%$ & $0.00 \%$ \\
\hline France & $0.00 \%$ & $0.00 \%$ & $0.00 \%$ & $0.00 \%$ \\
\hline Germany & $0.52 \%$ & $0.00 \%$ & $0.00 \%$ & $0.00 \%$ \\
\hline Ireland & $0.77 \%$ & $0.00 \%$ & $0.00 \%$ & $0.00 \%$ \\
\hline Italy & $0.00 \%$ & $0.00 \%$ & $0.00 \%$ & $0.00 \%$ \\
\hline Netherlands & $0.75 \%$ & $0.00 \%$ & $0.00 \%$ & $0.76 \%$ \\
\hline Spain & $0.00 \%$ & $0.00 \%$ & $0.00 \%$ & $0.00 \%$ \\
\hline Switzerland & $0.00 \%$ & $0.00 \%$ & NA & $0.00 \%$ \\
\hline $\begin{array}{l}\text { United } \\
\text { Kingdom }\end{array}$ & $-0.27 \%$ & $-7.37 \%$ & $0.00 \%$ & $0.00 \%$ \\
\hline United States & $0.00 \%$ & & $0.97 \%$ & $0.24 \%$ \\
\hline
\end{tabular}

Table 5. 2016 Annualized Change in Inflation, Trade, and Unemployment (Unem.)

\begin{tabular}{|l|c|c|c|}
\hline Country & $\begin{array}{c}\text { Change in } \\
\text { Inflation }\end{array}$ & Change in Trade & Change in Unem. \\
\hline Belgium & $0.00 \%$ & $0.00 \%$ & $-0.20 \%$ \\
\hline China & $0.00 \%$ & $0.00 \%$ & $-0.12 \%$ \\
\hline France & $-0.44 \%$ & $0.00 \%$ & $0.00 \%$ \\
\hline Germany & $0.00 \%$ & $0.00 \%$ & $0.00 \%$ \\
\hline Ireland & $-0.36 \%$ & $0.00 \%$ & $0.00 \%$ \\
\hline Italy & $-2.01 \%$ & $0.00 \%$ & $0.00 \%$ \\
\hline Netherlands & $0.45 \%$ & $0.00 \%$ & $0.00 \%$ \\
\hline Spain & $0.00 \%$ & $0.00 \%$ & $-0.19 \%$ \\
\hline Switzerland & $0.00 \%$ & $0.00 \%$ & $0.00 \%$ \\
\hline United Kingdom & $-0.10 \%$ & $0.00 \%$ & $0.00 \%$ \\
\hline United States & $0.00 \%$ & $0.00 \%$ & $0.00 \%$ \\
\hline
\end{tabular}

\section{The Belgian Economy}

The Belgian short-term model results show that Brexit caused no decline in consumption in Belgium, but caused a decline in GDP of $0.35 \%$. By United States standards, the Belgian model results may seem counterintuitive. However, the U.S. economy is much more dependent on private consumption than is the Belgian economy. Table 6 provides the percent of GDP for the U.S. and Belgium related to private consumption, investment, government consumption, and net exports in the fourth quarter of 2016. 
Table 6. PerCent of GDP by Economic Indicator

\begin{tabular}{|l|c|c|}
\hline Economic Indicator & Belgium & United States \\
\hline Private Consumption & $52.92 \%$ & $68.9 \%$ \\
\hline Private Investment & $21.26 \%$ & $16.4 \%$ \\
\hline Government Consumption & $25.70 \%$ & $17.6 \%$ \\
\hline Net Exports & $0.12 \%$ & $-2.9 \%$ \\
\hline
\end{tabular}

On a forecast basis, the effect of Brexit on Belgium's GDP is driven by a significant decline in investment (particularly foreign direct investment), and the effect of investor expectations on the Belgian economy. When UK citizens voted to leave the EU, most economists believed that this vote would result in a substantial decline in GDP throughout Europe (see section "Literature Review").

If one believes that European GDP will decline because of Brexit, it is reasonable to assume that the Belgian economy will be strongly impacted because Brussels is the de facto capital of the European Union. The European Commission has 33,000 employees and the European Parliament has 6,000, for a total of 39,000 employees (European Commission 2016). Over 27,000 of these employees work in Belgium (European Commission 2015).

EU administrative expenses are approximately $6 \%$ of the EU budget, which was 68 billion euros in 2015 (European Commission 2016). Thus, total EU administrative expenses were approximately 4.08 billion euros. Based on the percent of EU employees who work in Belgium (63.64\%), the paper estimates that the EU spent 2.60 billion euros in Belgium on administrative expenses. These staff expenses have helped to boost the Belgian economy by increasing both private consumption and domestic investment. ${ }^{9}$

The EU also spends substantial sums on consultants, who fly in and out of Brussels, stay at Belgian hotels, and eat in Belgian restaurants. Additionally, both the European Commission and the European Parliament tend to attract tourists to Belgium. Since the euro was adopted in 1999, Belgian hotel and restaurant consumption has increased by $60.56 \%$, and the number of non-resident tourists has increased by $31.18 \%$. Over 17 million tourists visited Belgium in 2015 (Calculated from Federal Reserve Economic Data and Eurostat).

Brexit could have a substantial effect on the Belgian economy, as shown by the estimated decline in FDI and GDP given in Table 4 above. The UK is currently paying approximately $12.57 \%$ of the EU budget (HM Treasury 2015). A $12.57 \%$ decline in staff expenses will reduce EU administrative expenses in Belgium by 326.82 million euros. These assumed staff layoffs would decrease consumption, decrease tourism, harm the tourist industry, and decrease GDP in Belgium.

To an investor, these potential reductions make Belgium a higher risk investment with little upside and substantial downside. Thus, it is reasonable to assume ceteris paribus a decline in FDI and GDP as shown by the model results.

\footnotetext{
${ }^{9}$ Brussels has been both positively and negatively affected by the centralization of EU operations in Brussels. For an overview of some of the negative effects, please see Romańczyk (2012).
} 


\section{Long Term Economic Effects}

As mentioned previously, the OECD found that UK GDP would be $3 \%$ smaller in 2020 and 5\% smaller in 2030, equivalent to a cost per household of 2,200 GBP by 2020 and 3,200 GBP by 2030 (Kierzenkowski et al. 2016).

GDP was estimated for each of the eleven countries for the period 20182030 using a Vector Auto Regression (VAR) model with two lags. Brexit is an exogenous variable, and the endogenous variables are consumption, foreign direct investment, GDP, and net exports. For comparison purposes, model results for the long-term and short-term models are given in Table 7 below.

Probabilities (ranging from 0 to 1) were calculated for the estimated Brexit coefficient. A probability of 0.05 indicates $95 \%$ confidence that the true coefficient is not zero. A probability of 0 indicates $99 \%$ confidence that the true coefficient is not 0 . Consistent with standard econometric practice, the true coefficient is assumed to be $0(0.00 \%$ change $)$ if the estimated probability is greater than 0.05 .

The regression results indicate that Brexit will have no effect on GDP in any of the countries in the study. The long-term effect is assumed to be zero because the probability is greater than 0.05 .

Table 7. Average Long-Term (2018-2030) and Short-Term (2016-2017) Effect of Brexit on GDP

\begin{tabular}{|l|c|c|c|}
\hline Country & $\begin{array}{c}\text { Short Term } \\
\text { Effect }\end{array}$ & $\begin{array}{c}\text { Long Term } \\
\text { Effect }\end{array}$ & $\begin{array}{c}\text { Long Term } \\
\text { Probability }\end{array}$ \\
\hline Belgium & $-0.35 \%$ & $-0.83 \%$ & 0.6161 \\
\hline China & $0.00 \%$ & $3.87 \%$ & 0.0561 \\
\hline France & $0.00 \%$ & $0.15 \%$ & 0.3903 \\
\hline Germany & $0.00 \%$ & $0.17 \%$ & 0.5670 \\
\hline Ireland & $0.00 \%$ & $-1.24 \%$ & 0.5651 \\
\hline Italy & $0.00 \%$ & $0.16 \%$ & 0.6574 \\
\hline Netherlands & $0.76 \%$ & $0.38 \%$ & 0.2987 \\
\hline Spain & $0.00 \%$ & $-0.11 \%$ & 0.3645 \\
\hline Switzerland & $0.00 \%$ & $-0.04 \%$ & 0.8374 \\
\hline $\begin{array}{l}\text { United } \\
\text { Kingdom }\end{array}$ & $0.00 \%$ & $0.04 \%$ & 0.8540 \\
\hline United States & $0.00 \%$ & $0.00 \%$ & 0.9846 \\
\hline
\end{tabular}

\section{Political Effects}

The paper hypothesizes that election results in one country may affect election results in other countries. We notice that similar governments tend to be elected in different developed countries. For example, the 2015 Conservative victory in the UK was followed by a Republican Party victory in the United States presidential race in 2016. Therefore, it is reasonable to assume that the 2016 Brexit vote results might influence the 2017 election results in Europe.

The paper reviews presidential and parliamentary election results for the period 1945-2017 in Germany, the United Kingdom, and the United States (see 
Table 7). The U.S. and the U.K. elected similar governments in 12 of 17 election cycles (71\%); and Germany and the U.K. elected similar governments in 11 of 15 election cycles $(73 \%)$.

Table 8. Winning Party in International Elections (1945-2017)

\begin{tabular}{|l|c|c|c|}
\hline Years & Germany & U.K. & U.S. \\
\hline $1945-1948$ & & Labour & Democratic \\
\hline $1949-1952$ & CDP & Conservative & Republican \\
\hline $1953-1956$ & CDP & Conservative & Republican \\
\hline $1957-1961$ & SDP & Conservative & Democratic \\
\hline $1963-1964$ & SDP & Labour & Democrat \\
\hline $1966-1969$ & SDP & Labour & Republican \\
\hline $1969-1972$ & SDP & Conservative & Republican \\
\hline $1974-1976$ & SDP & Labour & Democratic \\
\hline $1979-1980$ & SDP & Conservative & Republican \\
\hline $1981-1984$ & CDP & Conservative & Republican \\
\hline $1987-1988$ & SDP & Conservative & Republican \\
\hline $1990-1992$ & CDP & Conservative & Democratic \\
\hline $1995-1997$ & SDP & Labour & Democratic \\
\hline $1998-2001$ & SDP & Labour & Republican \\
\hline $2001-2004$ & SDP & Labour & Republican \\
\hline $2005-2008$ & SDP & Labour & Democratic \\
\hline $2009-2013$ & CDP & Conservative & Democratic \\
\hline $2015-2017$ & CDP & Conservative & Republican \\
\hline
\end{tabular}

Note: CDP is the Christian Democratic Party; SDP is the Social Democratic Party.

The paper attributes this trend to the following factors:

1. Similar parties (e.g., Labour in the U.K. and the Democratic Party in the U.S.) are in close communication with one another through international organizations, and often provide consulting services to one another.

2. A victory by a similar party in one country motivates a party's base in another country, which increases that party's number of volunteers, and increases donations, thereby further increasing the number of volunteers, etc. This dynamic often leads to electoral victories.

3. A "surprise victory," such as Brexit in the U.K., ${ }^{10}$ provides similar parties in other countries with a built-in excuse in case polls show them performing poorly. For example, when U.S. public opinion polls showed Donald Trump losing by double-digit margins, the Trump campaign responded by pointing out that experts thought the Brexit campaign was going to lose also.

The paper tested the hypothesis that election results in one country can affect election results in other countries by estimating a political effects model that compared public opinion polls for nationalist parties in eleven European countries

\footnotetext{
${ }^{10}$ On June 22, 2016, a Populus poll found that Brexit would lose by a margin of 55\%-45\% (Financial Times 2016).
} 
for the period September 1, 2015 to April 7, 2017. The list of parties is given in Table 3, and the model is given in section "Political Models", above. The results of the analysis are provided in Table 9.

Table 9. European Public Opinion Polls Before and After the Brexit Vote

\begin{tabular}{|l|c|c|c|c|c|}
\hline Country & $\begin{array}{c}\text { Number of } \\
\text { Polls }\end{array}$ & $\begin{array}{c}\text { Pre-Brexit } \\
\text { Percent }\end{array}$ & $\begin{array}{c}\text { Post-Brexit } \\
\text { Percent }\end{array}$ & $\begin{array}{c}\text { Brexit } \\
\text { Effect }\end{array}$ & Prob. \\
\hline Austria & 28 & $45.19 \%$ & $50.13 \%$ & $0.43 \%$ & 0.8663 \\
\hline Denmark & 138 & $20.11 \%$ & $17.62 \%$ & $-0.04 \%$ & 0.3698 \\
\hline Finland & 44 & $11.86 \%$ & $9.02 \%$ & $0.35 \%$ & 0.0371 \\
\hline France & 335 & $27.57 \%$ & $26.09 \%$ & $-0.91 \%$ & 0.1858 \\
\hline Germany & 378 & $9.84 \%$ & $11.75 \%$ & $1.89 \%$ & 0.0000 \\
\hline Italy & 440 & $26.24 \%$ & $28.56 \%$ & $-0.02 \%$ & 0.3273 \\
\hline Netherlands & 172 & $33.63 \%$ & $27.81 \%$ & $-5.78 \%$ & 0.0000 \\
\hline Hungary & 88 & $15.29 \%$ & $15.05 \%$ & $-1.09 \%$ & 0.1770 \\
\hline Poland & 146 & $33.68 \%$ & $32.93 \%$ & $-0.74 \%$ & 0.2894 \\
\hline Portugal & 34 & $5.29 \%$ & $6.27 \%$ & $0.82 \%$ & 0.1136 \\
\hline Sweden & 174 & $19.99 \%$ & $19.72 \%$ & $-0.29 \%$ & 0.5105 \\
\hline
\end{tabular}

Notes: 1.The Pre-Brexit Percent is the average of polls taken prior to June 23, 2016. The PostBrexit Percent is the average of polls taken after June 23, 2016.

2. The Brexit effect is the estimated Brexit coefficient as defined in Section "Political Models".

Table 9 shows that the Brexit vote had no effect on voter support for nationalist parties in eight countries; that it increased voter support in Germany and Finland; and that it decreased voter support in the Netherlands.

\section{Analysis of Results}

The paper expected to find that Brexit would result in slight declines in GDP; would cause an increase in the civilian unemployment rate; and would have no significant effect on election results. The paper finds that the effect of Brexit on GDP results was mixed; that Brexit caused the unemployment rate to fall in three countries but had no effect on the unemployment rate in eight countries; and that Brexit modeling results have had a material effect on several elections.

The most common empirical result is that Brexit will not have a significant effect on economic or political results. The paper found that Brexit had a significant effect in only 19 out of 88 economic models, and only two out of 11 political models.

In great part, the story of Brexit is the story of modeling. Prior to the Brexit vote, economists had forecast a loss of UK GDP of $2.3 \%$ to $9.5 \%$, ceteris paribus. For example, modelers implicitly assumed that the Bank of England would take no action to mitigate the potential effects of Brexit.

However, all other things tend not to remain equal. The Brexit vote occurred on June 23, 2016. On August 4, 2016, the Bank of England (BOE) lowered the UK's Bank Rate from $0.50 \%$ to $0.25 \%$ and engaged in other types of monetary 
stimulus. Many political observers believed that the BOE's new monetary stimulus program prevented a recession in the UK.

On January 6, 2017, Andy Haldane, the BOE's chief economist, admitted that their forecasts were wrong, and that the UK has had strong economic performance since the Brexit vote.

However, the Brexit vote may have had a negative impact on voter support (as measured by public opinion polls) for some of the nationalist and eurosceptic parties throughout Europe. A comparison of the June 2016 polls with the July 2016 polls found that over a one-month period, voter support for selected nationalist parties (see Table 3) fell by $0.50 \%$ in Finland, $1.74 \%$ in Germany, $0.15 \%$ in Italy, $0.02 \%$ in the Netherlands, $3.89 \%$ in Poland, and $1.20 \%$ in Portugal.

\section{Conclusion}

The major economic impact of Brexit to date is the decline in the value of the British Pound (GBP), which fell from USD \$1.467 on June 20, 2016 to $\$ 1.204$ on January 16, 2017. A decline in the value of a country's currency means that its products will be less expensive on the world market. Ceteris paribus, such a decline also decreases a country's unemployment rate, and its citizens will pay more for imported goods.

The paper examines the economic effect of the Brexit vote on the United Kingdom and on its ten largest goods trading partners as defined by HM Revenue and Customs (2016). Macroeconomic data was collected for eleven countries, seven of which are current members of the European Union. These eleven countries are Belgium, China, France, Germany, Ireland, Italy, the Netherlands, Spain, Switzerland, the United Kingdom, and the United States of America (US).

Future trade negotiations may have a positive or negative impact on imports, exports, and GDP for the UK and the ten countries mentioned above.

For each country, the paper provides short-term results by comparing economic results for the second quarter of 2016 to economic results for the period 2016 Q3 to 2017 Q3. Long-term economic results for the same eleven countries are then estimated for the period 2018-2030. The 2018-2030 time period was chosen because it is the period used by Kierzenkowski et al. (2016). This period was used because Kierzenkowski et al. (2016) provided one of the more extreme forecasts and were the only authors who adequately defined the meaning of the phrase "long-term".

The paper also estimates the political effect of Brexit on elections in eleven European countries from 2016 to 2019. These countries are Austria, Denmark, Finland, France, Germany, Italy, the Netherlands, Hungary, Poland, Portugal and Sweden.

The short-term empirical analysis of macroeconomic data in eleven countries shows that Brexit has contributed to a decline in exchange rates and inflation, but has had only a slight effect on consumption, foreign direct investment, trade, and unemployment. 
The long-term empirical analysis estimates that Brexit will have no effect on GDP in the eleven countries in the study. The analysis of public opinion polls indicates that Brexit has increased support for nationalist or eurosceptic political parties in two countries, and decreased support in one country; and that economic forecasts may have contributed to the decline in voter support for nationalist parties in five countries.

Finally, the paper shows that pre-Brexit economic forecasts were erroneous because they failed to account for either consumer expectations or the future actions of the Bank of England.

\section{Acknowledgments}

Thanks to Dr. Katarzyna Romańczyk and Ron Knecht (J.D.) for their helpful comments and suggestions, and to Gina L. Serman Reid (B.S.), manuscript editor.

\section{References}

Associated Press (2017) Bank of England economist: Brexit predictions were wrong Fox News, January 6, 2017. Retrieved from http://fxn.ws/2s2jxah. [Accessed 7 February 2017].

Bank of England (2016) Statistical Interactive Database - official Bank Rate history. Retrieved from http://bit.ly/1Lpqt2v. [Accessed 14 February 2017].

BBC News (2017) How has Economy Fared Since Brexit Vote. BBC News, January 17, 2017. Retrieved from http://bbc.in/2aULXJR. [Accessed 12 February 2017].

Begg I (2017) Making Sense of the Costs and Benefits of Brexit: Challenges for Economists. Atlantic Economic Journal, 45:299-315.

Belke A, Gros D (2017) The Economic Impact of Brexit: Evidence from Modelling Free Trade Agreements. Atlantic Economic Journal, August 2017. doi: 10.1007/s11293017-9553-7.

Bunn P, Le Roux J, Reinold K, Surico P (2017 February 6). The Consumption Response to Positive and Negative Income Changes Bank of England Working Paper No. 645. Retrieved from https://ssrn.com/abstract=2916082. [Accessed 14 February 2017].

Capital Economics (2016) The Economic Impact of Brexit. Woodford Investment Management, February 2016. Retrieved from http://bit.ly/1U6Ntbn. [Accessed 12 February 2017].

Chu B. (2016) Brexit latest: Bank saved 250,000 jobs by cutting rates after referendum, says Mark Carney. Independent Company, United Kingdom: July 2016. Retrieved from https://ind.pn/2jpjS1o. [Accessed 22 February, 2017].

De Meulemeester C (2016) Country risk: Experts say UK economy will quickly recover from Brexit shock. Euromoney, June 17, 2016. Retrieved from http://bit.ly/2BPh Pso. [Accessed 6 February 2017].

The Economist (2017) Britain and the EU, The Negotiator. The Economist, April 1, 2017: 10.

Els F. (2017) You can trust official Chinese GDP growth numbers - for now.Mining.com, Mining.com, January 24, 2017. Retrieved from http://bit.ly/2BOsQKJ. [Accessed 3 April 2017]. 
Eur-Lex (2008) Official Journal of the European Union. May 9, 2008. Retrieved from http://bit.ly/2GDSDbY. [Accessed 11 February 2017].

European Commission (2015) EU annual budget life-cycle: figures. Retrieved from http://bit.ly/29g6CTT. [Accessed 11 February 2017].

European Commission (2016) Economic Forecasts. Retrieved from http://bit.ly/2q5ys NS. [Accessed 13 February 2017].

Eurostat (n.d.a) EU expenditure and revenue 2014-2020. Retrieved from http://bit.ly/ 1tpip7K. [Accessed 2 April 2017].

Eurostat (n.d. b) EU Administration - staff, languages, and location. Retrieved from http://bit.ly/2BOFedA. [Accessed 2 April 2017].

Eurostat (2017a) Statistical Bulletin for Commission. Retrieved from http://bit.ly/2E 77fCt. [Accessed 2 April 2017].

Eurostat (2017b) Your key to European Statistics. Retrieved from http://bit.ly/1vbibQq. [Accessed 13 March 2017].

Fairless T, Buell T (2016) Draghi Urges Eurozone Governments to Help ECB Boost Economy. The Wall Street Journal, September 26, 2016.

Federal Reserve Economic Data (2017) Economic Research, Federal Reserve Bank of St. Louis. Retrieved from http://bit.ly/2hWtGPP. [Accessed 13 March 2017].

Financial Times (2016) Brexit Poll Tracker. Retrieved from http://bit.ly/2DWmZJd. [Accessed 7 April 2017].

The Guardian (2016) This is the Bank of England's all-action response to Brexit. August 4, 2016. Retrieved from http://bit.ly/2aA122H. [Accessed 21 February 2017].

Hannon P (2017) Global Uncertainty Gets Brushed Off in the U.S. and Europe. Market Watch, Fidelity Investments, January 22, 2017. Retrieved from http://bit.ly/2DV m8Z3. [Accessed 23 January 2017].

HM Revenue and Customs (2016) List of the Largest Trading Partners of the United Kingdom. Retrieved from http://bit.ly/1QSjeRe. [Accessed 25 October 2016].

HM Treasury (2015) European Union finances: 2015. Retrieved from http://bit.ly/1O e5r5e. [Accessed 11 February 2017].

Kierzenkowski R, Pain N, Rusticelli E, Zwart S (2016) The Economic Consequences of Brexit: A Taxing Decision. OECD Economic Policy Papers, No. 16., ISSN 222 $6583 \mathrm{X}$.

Lawder D (2016) China's central bank monitoring UK "Brexit" fallout-Zhou. Reuters, June 24, 2016. Retrieved from http://reut.rs/2nBzsqy. [Accessed 16 January 2018]

Matthijs M (2017) Europe After Brexit. Foreign Affairs, January/February 2017: 85-95.

Miethe J, Pothier D (2016) Brexit: What's at stake for the financial sector? DW Economic Bulletin 31, 365-72.

National Bureau of Statistics of China (2017) National Data. Retrieved from http://bit. ly/2FDZOQr. [Accessed 7 March 2017].

Obstfeld M (2016) The Initial Economic Impact of Brexit: An Update to Early December 2016. Brookings Papers on Economic Activity, Fall 2016, 359-366.

Oltermann P, Scammell R, Darroch G (2016) Brexit causes resurgence in pro-EU leanings across continent. The Guardian. [Accessed 4 February 2017].

The Organization for Economic Co-Operation and Development (2017). Main Economic Indicators. Retrieved from https://data.oecd.org. [Accessed 14 March 2017].

Ringe W (2016) The Irrelevance of Brexit for the European Financial Market. Oxford Legal Studies Research Paper No 3/2017 http://dx.doi.org/10.2139/ssrn.2902715.

Romańczyk K (2012) Transforming Brussels into an international city - Reflections on 'Brusselization'. Cities 29: 126-32.

Sampson T (2017) Brexit: The Economics of International Disintegration. Journal of Economic Perspectives 31(4): 163-84. 
Scuira L (2017) Brexit Beyond Borders: Beginning of the EU Collapse and Return to Nationalism. Journal of International Affairs 70(2): 110-23.

Seeking Alpha (2016) The Impact Of Brexit On China. Retrieved from http://bit.ly/2E yDwQJ. [Accessed 23 February 2017].

Slater A (2017) Brexit and world growth - what are the risks? Oxford Economics, July 2016 (13-16).

Stanzel A (2016) Brexit: An Opportunity for China. China Analysis, European Council on Foreign Relations, September 2016. Retrieved from http://bit.ly/2cQ6MV1. [Accessed 24 February 2017].

Swinford S (2016) Britain could be up to $£ 70$ billion worse off if it leaves the Single Market after Brexit, IFS warns. The Telegraph, August 10, 2016. Retrieved from http://bit.ly/2GH8JBC. [Accessed 7 February 2017].

Trading Economics (2017) Retrieved from http://bit.ly/2EcFeJJ. [Accessed 20 March 2017].

Van Reenen J (2016) Brexit's Long-Run Effects on the U.K. Economy. Brookings Papers on Economic Activity, Fall 2016, 367-380.

Van Santvoort A (2016) Canada's economy feeling effects of Brexit vote. Business Vancouver, June 26, 2016. Retrieved from http://bit.ly/2nylnuZ. [Accessed 25 June 2017].

Welfens P (2017) A Brexit Perspective. The International Economy, Summer 2017, 40-42.

Wyman O (2016) The Impact of the UK's Exit From the EU on the UK-based Financial Services Sector. TheCityUK, October 2016. 